\title{
The Exploitation of Children in the Novel Tempurung by Oka Rusmini (A Sociology of Literature Perspective)
}

\author{
Risa Anjelitha Ashar, Inriati Lewa, Muhammad Syafri Badaruddin \\ Faculty of Cultural Sciences - Hasanuddin University, Makassar, South Sulawesi, Indonesia
}

\begin{abstract}
This study aims to reveal the exploitation of children in Tempurung, a novel by Oka Rusmini. The data collection method used in this research is the literature study method. The method of data analysis is the qualitative method. The types of data that will be used in this study are from the novel. The results showed that there were two forms of child exploitation carried out by the parents in the novel. The forms of exploitation that are intended are (1) forced marriage of children, and (2) the sale of children in places of prostitution. The results of this research indicate that the father's act of forcibly marrying his daughter, and then exploiting his biological child, is immoral and condemnable. The implications of this research will inspire everyone to protect their children and not to do things that destroy the future of the child.
\end{abstract}

Keywords: child exploitation, Tempurung, Sociology of Literature.

\section{INTRODUCTION}

$\mathrm{T}$ alking about women, numerous studies reveal that they are still a vulnerable group who face a variety of issues such as poverty, natural disasters, conflicts, violence, and so on. This is occurring not only in Indonesia but also in other countries around the world. This is what Oka Rusmini expresses in her novel entitled Tempurung[1].

Tempurung is one of the novels that are very strong in describing various events in social life, especially the Balinese people. The novel describes the life of Balinese people, especially women who are full of pain. The woman in the novel is described as someone who does not have power over herself but is controlled by others. The novel also describes the lives of Balinese people who live by strong customary rules as a way of life. However, in the novel, some characters have behavior that deviates from the applicable rules.

The female characters are present very interesting to analyze in the novel. Each character is portrayed as a woman who is confronted with customs, culture, and society that adheres to the prevailing rules, values, and norms. The story starts with the presence of Ida Ayu or usually called Dayu. She is one of the characters in this novel from the Brahman caste which is very respected in the Balinese community. Dayu is always greeted with respect by people who know her.

Another character is Dayu's hubby, he is a strangely behaving writer. He will sometimes leave the house for a week without informing his wife. Suddenly, he informed his family via e- mail that he had departed for writing. After a short time at home, I went out again in search of creative inspiration.

Ni Luh Putu Saring is the next character. She is a young woman with a one-of-a-kind name given to her by her parents. Saring has a lovely body shape and a lovely face. She frequently expressed her dissatisfaction with her name, which was deemed uncommon.

The sociology of literature is a branch of cultural sociology. It investigates the social production of literature as well as its social consequences and The Tempurung Novel is an example of sociology literature. Deviations in behavior in Tempurung are said to occur in the family environment. Family, which is the closest person in human life, is described as someone who has the heart to do things that are not appropriate. The character of parents in the novel exploits children.

Exploitation means utilization for own benefit, suction, and blackmail (about human power). Biologically, children (plural children) are humans who are between the ages of birth and puberty, or between childhood and puberty in terms of development. A minor, often known as a minor, is generally referred to by the legal definition of a child. In comparison to adults, children have fewer rights and duties. In Regulation Number 35 of 2014, a child is somebody who is not 18 years old yet, including children who are still in the womb. Thus, all persons under the age of 18 are still categorized as children according to the law. From a legal point of view, exploitation, and children, then, child exploitation is an act of exploiting, extorting or coercing children for personal gain for whoever does it.

The exploitation of children is divided into two, namely economic and sexual abuse of children. This is explained in Law Number 35 of 2014 Section Explanation of Article 66. Economic exploitation of children is an act with or without the consent of a child who is a victim which includes. It includes, but is not limited to, prostitution, forced labor or services, slavery or practices that are similar to slavery, oppression, extortion, the use of physical, pornographic, or reproductive organs, or improperly transferring or transplanting organs and/or body tissues, or the use of children's power or ability to acquire material benefits. Meanwhile, sexual exploitation of children is All types of 
exploiting children's sexual organs or other organs for profit, including but not limited to obscenity and prostitution.

The exploitation of children described in the novel is carried out by parents, both father, and mother. They make their children as a tool for personal gain in various ways. The child who is supposed to be someone who is loved in the family is actually treated differently in Tempurung by Oka Rusmini. The child character, in this case, a woman, is even traded like goods.

The exploitation of children contained in the novel can also be found in today's society. A literary work is born as a picture of reality, either in the past, the time when the work was born, or in the future. This is what causes the relationship between literary works and social reality.

Thus, the approach that is considered appropriate is used by researchers to reveal and dismantle the problem, namely the sociology of literature approach. The most suitable theory in the sociology of literary theory was proposed by Alan Swingewood. This theory is considered appropriate to examine behavioral deviations contained in Tempurung by Oka Rusmini.

Laurenson and Swingewood in their novel Sociology of Literature[2] argue that although sociology and literature have certain differences, they have similarities. The similarity between the two lies in the object of study, namely humans. Meanwhile, the difference lies in the way of analysis and perspective. This is what makes them complementary even though there are differences between the two[3].

Thus, the sociology of literature is a reflective branch of literary research. The basic assumption of the sociology of literature is that the birth of literature is not in a social vacuum. In other words, social life is the trigger for the birth of a literary work. A literary work can be said to be successful when it can reflect its era[4].

Laurenson \& Swingewood[2] explains that in researching literary works using the sociology of literature, a sociologist must not only find historical and social reflections (reflections) or refractions in literary works but also articulate the values contained in the works. Thus, literature as a reflection of values and feelings refers to changes that occur in society. The same view is also expressed by Rahman[5]that literary studies with a sociological perspective place events concerning social life outside the workplace. In it can be seen how individuals are socialized into a social structure and their response to the experience.

Swingwood gave a warning against the meaning of the slogan "literature is a mirror of society". According to him, the slogan is owned, the awareness, and the intention. In creating a work, the author of course uses certain tools. Therefore, if a literary work is said to be a mirror of society, then the mirror is reclaimed by the use of these literary tools[2].
The description above implies that literary works, apart from being a mirror of social life, can also provide other images that may contradict what happened. This is so that the goals or things that the author wants to convey can be achieved. In this case, every literary work, including the novel that will be studied in this study, may add conditions that are different from those in reality. Therefore, Laurenson \& Swingewood then stated that literary works are "mirrors seizing" from reality.

This is in line with the opinion expressed by Teeuw[6] which explains that literary works can be said as (1) affirmation (determining existing norms), (2) restoration (expression of longing for norms that have been established). exists), (2) restoration (expression of longing for existing norms, obsolete), (3) negation (rebellion against current norms), (4) innovation (renewing existing norms). Painting reality in a literary work can be described in total as a reflection of reality or randomized in such a way according to the wishes and creativity of the author. So that the reality in the literary work can happen in the past, present, or in the future[7].

Swingwood (in Junus[8]) says that there are three approaches related to sociological literature, namely: (1) literature as a socio-cultural document approach, (2) literature as a social point of view approach, (3) literature as a socio-cultural document approach which focuses on the public's reception of a work. Based on these three things, the author will make a sociological approach that is in line with Swingwood's understanding which states that literary works are sociocultural documents that record an era.

Indonesia has many cultures[9]. This novel talks about women's lives dealing with their bodies, religion, culture, and society in Indonesia. It talks about women who live in an "absurd" of marriage. Deep down they don't want marriage, on the other hand, they need children, affection, love, care, and touch for their bodies. Women who are looking for love, affection, dreams, even they do not know what they want, sometimes are also afraid to dream. The women's bodies are not their own described in this novel. They often stutter when dealing with their bodies. A body they sometimes do not recognize. They don't know whether being a woman is a gift or a curse.

Thus, Tempurung by Oka Rusmini will be seen as a sociocultural document that records the state of a society at a certain time. This novel is no longer a complete reflection that reflects only one image, but a "cracked mirror" that can explain many things. I want to see how the behavior deviations are carried out by the characters in Tempurung by Oka Rusmini who is a researcher of today's society. In addition, the researcher will also reveal the responses of other characters in the novel in responding to these behavioral deviations. 


\section{OBJECTIVES OF STUDY}

This research is a sociological study with the following formulation of objectives; 1) to reveal the forms of child exploitation in Tempurung by Oka Rusmini, and 2) to reveal the motives behind the sale and exploitation of children in Tempurung by Oka Rusmini.

\section{RESEARCH METHODS}

This study applies a qualitative method to reveal the exploitation of children in Tempurung by Oka Rusmini. The qualitative method is an appropriate method used in this study to describe data based on interpretation and interpretation based on the facts of the story found in the work. The data collection method used is a literature study. This literature study method is carried out by examining the data sources carefully which is then described descriptively.

The data in this study are in the form of fragments that are directly related to deviations in the behavior of the characters contained in Tempurung by Oka Rusmini. This novel was published by Kompas Gramedia which was first printed in 2010. The novel was then reprinted in 2017 with a thickness of 404 pages.

The fragments obtained as data are then analyzed according to the themes and issues of this research. This research will use the theory of sociology of literature in solving the problem. The data obtained are qualitative in nature, namely data that describes behavioral deviations. Data analysis was carried out systematically following the formulation of the problem that had been stated previously.

In analyzing behavioral deviations that occur in the novel, of course it cannot be separated from the events that occur. The first thing to do is pay attention to every event that occurs in the novel. Furthermore, to answer the existing problem formulation, the data that has been found is then analyzed and interpreted using the theory of sociology of literature. After that, several ideas and concepts related to the research were put forward.

\section{FINDING AND DISCUSSION}

The exploitation of children is one of the strong actions depicted in Tempurung by Oka Rusmini. The exploitation of children in the novel is carried out by parents. The intended parents are the father and mother.

\subsection{Forced Marriage of Children}

Sipleg is one of the child characters who are victims of child exploitation in the novel. Sipleg is Songi's biological son who was exploited by his mother. He was forcibly married at a very young age to someone he did not know so that his mother would benefit. This can be seen from the following quote.

\section{Fragment 1}

Umur 16 tahun kedua orang tuanya mengawinkan perempuan tipis itu dengan lelaki desanya, Wayan
Payuk. Orang tua Sipleg yang berpenghasilan tidak jelas itu berharap perkawinan Sipleg dengan seorang pemilik tanah akan mampu mendongkrak kehidupan mereka. Menutupi kebutuhan hidup sehari-hari

(At the age of 16, her parents married the thin woman to her village man, Wayan Payuk. Sipleg's parents, whose income is unclear, hope that Sipleg's marriage to a landowner will be able to improve their lives. Cover the needs of daily life)

$$
\text { (Rusmini, 2017:77). }
$$

The quote above describes the actions of Sipleg's parents who married their children for personal gain. Sipleg's mother, Songi, who is in needs of money to cover her daily needs is not looking for a decent job that can provide her with a wage. Instead, he looked for another way, namely by marrying his son to a rich man. The goal is to improve their lives. So, Sipleg's parents deliberately married their child to a landowner who certainly had a lot of money so that he could earn a lot of money to meet his daily needs. In addition, by marrying his child he can also raise his social status. Thus, Sipleg is only used as a tool to fulfill the wishes of his parents, namely to boost his life.

The quote also describes that Sipleg was married when he was 16 years old. So, it can be said that when he was early married because he was still categorized as a child. In addition, early marriage is also categorized as a marriage that was forced by his parents. This can be seen through the following quote.

\section{Fragment 2 \\ Di punggung Sipleg-lah impian dan harapan itu dibenamkan secara paksa. Hasilnya rangkaian kemarahan beranak-pinak di otak dan aliran darah Sipleg. Dia juga tidak percaya pada kata- kata.}

(It was on Sipleg's back that those dreams and hopes were forcibly buried. The result is a series of anger proliferating in Sipleg's brain and bloodstream. He didn't believe in words either).

(Rusmini, 2017:77).

The quote above explains that there is no agreement on the part of Sipleg as a child in his marriage. This was done forcibly to fulfill the wishes of his parents. The dreams and hopes of his parents, namely wanting to get a better life, were even considered a burden for Sipleg. This is very clearly illustrated by Sipleg's feelings, which are full of anger. The word procreation means that anger is increasing day by day. It was stated that Sipleg's anger was in his brain and bloodstream. This illustrates that the anger has merged with Sipleg. Thus, it can be concluded that Sipleg never liked her marriage to the man chosen by her mother. Even so, the mother still did not pay attention to the wishes of the child. She still married her child to the man she wanted. The action 
of Sipleg's mother is tantamount to exchanging her child for money or in other words selling her child. This is supported by the following quote.

\section{Fragment 3}

Makanya, perempuan kumuh dan kurus itu tega menjual Sipleg kepada Payuk. Tanpa hati. Karena perempuan dekil itu memang tidak punya hati. Tidak punya rasa. Membiarkan adikadiknya kelaparan. Makanya adik-adik Sipleg mati.

(Hence, the slum and skinny woman had the heart to sell Sipleg to Payuk. Heartless. Because that dirty woman doesn't have a heart. Have no taste. Leaving the siblings to starve. That's why Sipleg's brothers died).

$$
\text { (Rusmini, 2017:95). }
$$

The quote above illustrates that Sipleg's mother did sell her child even without a heart. So, he did exchange his son for money to get what he wanted. He didn't even think about his son's feelings anymore. He only thought of a quick way so that he could fulfill his personal desire, namely to get a good social status and a lot of money. Thus, it can be said that the mother deliberately made her child as merchandise.

Songi is the only daughter Rimpig has. He is also the youngest child in the family. However, his mother still had the heart to sell it for personal gain, namely social status. He sold Songi to people who were rich and had good social status. He even sold his son at a high price. The quote below also explains that Songi has sold the only daughter he has at a high price.

\section{Fragment 4}

Rimpig menjual anak perempuan satu-satunya, Songi. Perempuan tercantik desanya. Banyak lelaki datang ingin mengambil perempuan enam belas tahun itu untuk dijadikan istri. Rimpig jual mahal

(Rimpig sold his only daughter, Songi. The most beautiful woman in the village. Many men came to take the sixteen-year-old woman as a wife. Rimpig sells expensive)

(Rusmini, 2017: 114).

Here is to describe that Songi's character who was also exploited by his mother. If a child is sold, then the child can be equated with the merchandise. He even gave a high price benchmark for people who wanted their children. Not only that, Songi who has advantages is even used by his mother for things that are not good. With Songi's beauty, her mother sold her expensively for personal gain. This is supported by the following quote.

\section{Fragment 5}

Sampai seorang pengusaha datang, entah dari mana asalnya. Rimpig tahu lelaki berkulit keju itu memiliki banyak uang. Songi pun dijual dengan harga mahal. Banyak orang berminat. Dia jadi kaya raya. Uangnya banyak. Dia membeli tanah, rumahnya dia perbaiki, juga sanggah, tempat ibadahnya. Bahkan dia ikut membantu warga desa yang kekurangan uang

(Until a businessman came along, out of nowhere. Rimpig knew the cheese-skinned man had a lot of money. Songi was sold at a high price. Many people are interested. He got rich. It's a lot of money. He bought land, he repaired his house, also argued, his place of worship. He even helped the villagers who were short of money)

(Rusmini, 2017: 114).

The quote above describes the character Songi who was sold by his mother to a cheese-skinned man. Cheese-skinned men can be interpreted as men who come from outside Indonesia or are often called 'foreigners'. After knowing that the man must have a lot of money Songi was sold at a high price. Thus, it is very clear that his mother did sell Songi to the man to earn a lot of money and become rich. The proceeds from selling his son he used to improve his life.

Parents should look after, nurture, and educate their children. However, in this novel, the character of Pasung as a father is depicted as not carrying out this obligation. Likewise, with Songi and Rimpig as mother figures. In general, in a family, parents are also obliged to work to earn a living to support their family. However, in this novel, parents are looking for other ways to earn money, namely by selling their children. His son is then blackmailed to support the family. Pasung, Songi, and Rimpig are depicted as parent figures who willingly sell their underage children

\subsection{Selling Children in Prostitution}

Besides Sipleg, Songi as a child was also exploited by his parents. Songi is the second character who becomes a victim of child exploitation in Tempurung. The exploitation of children by Songi's parents was carried out in prostitution. They sold their child in a prostitution place. This is illustrated by the following quote.

\section{Fragment 6}

Ibunya, Ni Nyoman Songi pelacur kecil yang dijual bapaknya sejak haid pertama. Diperas untuk menghidupi keluarga bapaknya yang suka kawin. Songi kecil memang tumbuh menjadi perempuan cantik.

(His mother, Ni Nyoman Songi, was a little prostitute who had been sold by his father since her first period. Blackmailed to support his 
father's family who likes to marry. Little Songi did grow into a beautiful woman).

(Rusmini, 2017: 106).

The quote above describes Songi's character who was exploited by his father in a prostitution area. Songi is sold at a very young age, namely during the first menstruation. Girls generally get their first menstrual period at the age of eleven to fourteen years. So it can be concluded that Songi was sold by his father when he was in his teens and has lived his days as a prostitute since he was a child. This can be proven through the following quote.

\section{Fragment 7}

"Sudah berapa tahun Songi menjadi pelacur?"

"Ku dengar sejak usia 15 tahun."

"Kau tahu berapa usianya sekarang?"

"Dua lima, mungkin lebih."

"Sudah habis dia"

("How many years has Songi been a prostitute?"

"I heard since I was 15 years old."

"Do you know how old he is now?"

"Two five, maybe more."

"He's finished")

(Rusmini, 2017: 130).

From here, the character of Songi is depicted who was sold by his father when he was a teenager, fifteen years to be exact. As illustrated in the quote above, Songi is twenty-five years old. So, it could be said that she had been a prostitute and supported her family for ten years. Teenagers who should be in school instead live their lives in prostitution. Besides being sold at a very young age, he was also used as a tool to make money by his father. The use of the word 'blackmailed' proves that Songi is forcibly forced to support his family in an unworthy way.

The advantages possessed by a child is a pride for his parents. However, in the novel, Songi's strengths are that he has a beautiful face and is even abused by his parents. The beauty that is the strength that Songi has is used as an attraction so that he is attracted by many men. Songi's beauty is described in the following quote.

\section{Fragment 8}

Songi kecil memang tumbuh menjadi perempuan cantik. Kulitnya putih dan bersih, dadanya subur, kakinya indah. Matanya mata penari yang liar, siap mencengkram pada lelaki. Padahal Songi tidak bisa menari.

(Little Songi did grow into a beautiful woman. Her skin is white and clean, her chest is lush, her legs are beautiful. Her eyes are wild dancer's eyes, ready to grab hold of a man. Even though Songi cannot dance).
(Rusmini, 2017: 106=107).

From the quote above, it can be seen that Songi's character has white and clean skin. As is known, white and clean skin is the standard of Indonesian women's beauty. It is also described that she has a fertile chest, beautiful legs, and wild dancer eyes which can certainly attract the attention of men easily. Songi's advantages were used as an attraction by his parents so that he was sold to a prostitution place. This is also supported by the following quote.

Not only was his father exploited, but Songi was also exploited by his mother. The father exploits Songi by being sold into prostitution, while the mother exploits him by selling him to rich people. Her mother's purpose for doing this was to gain social status. This can be seen through the following quote.

\section{Fragment 9}

Dia telah menjual Songi, adik perempuan mereka untuk status sosial. Rimpig merasa mata Rabug itu menerornya. Mata itu seolah mengupas semua dosanya. Seluruh pikiran-pikiran buruknya.

(He had sold their little sister Songi for social status. Rimpig felt Rabug's eyes terrorizing him. Those eyes seemed to peel away all his sins. All the bad thoughts).

(Rusmini, 2017: 116).

Parents should not exploit their children. Parents who want to earn income to support themselves and their families should use good and right methods. They should be looking for a decent job. If parents do this, it will have an impact on the personal and life of the child in the future.

The exploitation of children is not only found in novels. However, it can also be found in social reality. The description of child exploitation that occurs in social reality can be seen through the following news excerpts.

Other Fragment (Tribun Bali, March 1, 2019).

Selasa, 8 Januari 2019, Direskrimum Polda Bali berhasil mengamankan lima anak di bawah umur korban Tindak Pidana Perdagangan Orang (TPPO) dan dua orang sebagai tersangka TPPO, Jumat (4/11). Kedua tersangka masingmasing seorang wanita berinisial NKS (49) dan NWK (51). Mereka ditangkap di $3 B$ Jalan Sekar Waru 3B Sanur, Denpasar Selatan.Sadar atau tidak, mereka sudah mengeksploitasi manusia dalam bentuk yang terkonsep yakni human trafficking. Meggunakan jasa tenaga kerja anak di bawah umur untuk menarik simpati para tamu.

(Tuesday, January 8, 2019, the Bali Police Direskrimum managed to secure five minors victims of the Trafficking in Persons (TPPO) and two people as suspects for TIP, Friday (4/11). The two suspects are a woman with the initials NKS (49) and NWK (51). They were arrested at 3B Jalan Sekar Waru 3B Sanur, South Denpasar.Consciously or not, they 
have exploited humans in a conceptualized form, namely human trafficking. Using the services of child labor to attract the sympathy of the guests.)

In the description above, it is reported that in Denpasar Bali there are cases of exploitation of minors. Children are used as a tool to attract the attention of guests so that the parties concerned can get a lot of benefits. Bali is said to be a destination for child exploitation. In Bali, which is a tourist area, many children are used as trading tools. After this incident spread and disturbed the community, several precautions were taken by the Bali Police and their staff. The same thing happened not only in Bali but also in all parts of Indonesia.

The behavior carried out by the parents in the novel and the parents, in reality, are categorized as deviant because they have violated the point of Pancasila verse 2, namely Just and Civilized Humanity. In the verse, it is said that one must recognize and treat humans according to their dignity as creatures of God Almighty. However, children are instead treated like goods which are then sold to other people with the aim that their parents get money and their personal interests including social status.

In addition to violating Pancasila paragraph 2, the behavior of exploiting children violates Law Number 35 of 2014 concerning Child Protection, the fourth part of article 26 concerning the Obligations and Responsibilities of Parents and Families. The article reads: Parents are obliged and responsible for: a) Raising, nurturing, educating, and protecting children; b) Growing children according to their abilities, talents, and interests; c) Preventing child marriage; and d) Providing character education and inculcating values and manners to children.

Parents who commit acts of child exploitation can be said to have not carried out their obligations and responsibilities in accordance with the law. They behave deviate from the law in force in Indonesia. In the first paragraph of the law above, parents are obliged and responsible for nurturing, nurturing, educating, and protecting their children. The opposite is actually done by the parent character in the novel. They even sold his son when he was in his teens. They deliberately do that to improve social status and earn income.

The case of child exploitation that occurs in society shows that the Tempurung by Oka Rusmini has a relationship with the conditions that occur in reality. Although the way of child exploitation depicted in the novel and reality is slightly different. However, the case is still considered as a form of exploitation and it is still said to be behavior that deviates from the applicable rules.

\section{CONCLUSION}

Based on the results of research that it was found that the exploitation of children in the novel by the characters Songi, Rimpig, and Pasung as parents is a stupid act based on property interests. They exploit their children by forcibly marrying them off for personal gain. This is an act that ignores children's rights.

Some of the problems faced by female characters in this novel are related to (1) women's sex drive, (2) domestic life, (3) women's biology, (4) women's economic situation, (5) second-class women (6) exploitation of women's sex, (7) women's self-confidence, and (8) women as heads of families. The exploitation of children in the novel is in the form of forcibly marrying children and selling children in prostitution. All of these revealed by using the study of Sociology of Literature Perspective.

\section{REFERENCES}

[1] O. Rusmini, Tempurung. Jakarta: Kompas Gramedia, 2017.

[2] D. Laurenson and A. Swingewood, The Sociology of Literature. London: Granada Publish Limited, 1972.

[3] A. Sugiyartati, B. Arafah, F. Rahman, and M. Makka, "Cultural Values in Oral Literature of Krinok: Antropolinguistic Study," Lang. Lit. J. Linguist. Lit. Lang. Teach., vol. 4, no. 2, pp. 316321, 2020, doi: 10.30743/1l.v4i2.3099.

[4] T. Tahir, F. Rahman, and Herawaty Abbas, "The Persistent Fisherman's Spirit in Hemingway's The Old Man and The Sea," Musamus J. Lang. Lit., vol. 3, no. 1, pp. 36-48, 2020, doi: https://doi.org/10.35724/mujolali.v3i01.3303.

[5] F. Rahman, "Sastra Anak Dalam Persimpangan," J. Lensa Budaya, vol. 5, no. $1,2010$.

[6] A. Teeuw, Sastra dan Ilmu Sastra. PT. Dunia Pustaka Jaya, 2015.

[7] A. M. Akhmar, "Penceritaan Dan Refleksi Historis Dan Budaya Dalam Roman Sang Jenderal Karya Herman Jan Friedericy," J. Ilmu Budaya, 2019, [Online]. Available: http://journalold.unhas.ac.id/index.php/jib/article/download/6812/3753.

[8] U. Junus, Sosiologi Sastra Persoalan Teori dan Metode. Selangor: Dewan Bahasa dan Pustaka, 1986.

[9] M. R. A. Latief, N. J. Saleh, and A. Pammu, "The effectiveness of machine translation to improve the system of translating language on cultural context," IOP Conf. Ser. Earth Environ. Sci., vol. 575, no. 1, 2020, doi: 10.1088/1755-1315/575/1/012178.ol. 575, no. 1, 2020, doi: $10.1088 / 1755-1315 / 575 / 1 / 012178$. 